\title{
A violência na escola de educação básica em diálogo reflexivo com Benjamin, Adorno e Rosa'
}

\section{Violence at the elementary school in reflective dialogue with Benjamin, Adorno and Rosa}

\section{La violencia en la escuela de educación básica en dialogo reflexivo con Benjamín, Adorno y Rosa}

\begin{abstract}
Bruno Pucci2
Universidade Metodista de Piracicaba, Faculdade de Ciências Humanas, Professor Titular no Programa de Pós-graduação em Educação
\end{abstract}

Resumo: Neste artigo se propõe dialogar com as reflexões filosófico-estéticas e formativas de Walter Benjamin, Theodor Adorno e Guimarães Rosa sobre a problemática da "violência e educação", na perspectiva de problematizar e enfrentar a violência como barbárie, que perpassa as relações sociais e educacionais no atual quadro de dominação e de hegemonia do sistema capitalista neoliberal. E para realizar esse percurso, pretende-se o texto trilhar os seguintes passos: a violência reinante na escola de educação básica; Walter Benjamin e a crítica da violência; a violência nos escritos de Theodor Adorno; a violência como puro meio em A Benfazeja, de Guimarães Rosa; a violência divina na formação dos educandos.

Palavras-chave: Violência e educação. Violência como puro meio. Violência como barbárie. Violência benfazeja. Violência divina na educação.

Abstract: This article proposes to dialogue with the philosophical-aesthetic and formative reflections of Walter Benjamin, Theodor Adorno and Guimarães Rosa on the problematic of "violence and education", with a view to problematizing and facing violence as barbarism, which passes by social and educational relations in the current framework of domination and hegemony of the neoliberal capitalist system. In order to carry out this course, the text intends to follow the

\footnotetext{
Agradeço à Sandra Elisa Réquia Souza, doutoranda em Educação na UFSM, pela leitura e correção deste artigo, e ao colega de GT da ANPEd, Amarildo Luiz Trevisan, pela leitura crítica, bem como pela ajuda na elaboração do último tópico do texto.

2 Doutor em Educação: História, Política, Sociedade pela Pontifícia Universidade Católica de São Paulo; Mestre em Educação pela Universidade Metodista de Piracicaba.
} 
steps: Violence in the elementary school; Walter Benjamin and the critique of violence; Violence in the writings of Theodor Adorno; Violence as a pure mean in "A Benfazeja", by Guimarães Rosa; Divine violence in the students' formation. Keywords: Violence and education. Violence as a pure mean. Violence as barbarism. Benevolent violence. Divine violence in education.

Resumen: Este artículo se propone a dialogar con las reflexiones filosófico, estéticas y formativas de Walter Benjamin, Theodor Adorno y Guimarães Rosa, sobre la problemática de la "violencia y educación", en la perspectiva de problematizar y enfrentar la violencia como barbarie, que recorre las relaciones sociales y educacionales en el actual cuadro de dominación y de hegemonía del sistema capitalista neoliberal. Y, para realizar este trayecto, pretende el texto recorrer los siguientes pasos: La violencia reinante en la escuela de educación básica; Walter Benjamin y la crítica de la violencia; La violencia en los escritos de Theodor Adorno; La violencia como puro medio en "A Benfazeja", de Guimarães Rosa; La violencia divina en la formación de los educandos.

Palabras clave: Violencia y educación. Violencia como puro medio. Violencia como barbarie. Violencia benéfica. Violencia divina en la educación.

\section{A UIOLÊNCIA REINANTE NA ESCOLA DE EDUCAÇÃO BÁSICA}

As forças históricas, que produzem o terror, nascem da própria estrutura social. (ADORNO, 2001).

Nenhuma das grandes barbáries da história humana foi consumada sem o silêncio da maioria. E o silêncio sempre se inicia no cotidiano. (BRUM, 2017).

A escola de educação básica se apresenta como uma instituição educativa das crianças, dos adolescentes e dos jovens de nossa sociedade, sendo o primeiro nível do ensino escolar no Brasil. Ela compreende três etapas: a educação infantil (para crianças com até 5 anos), o ensino fundamental (para alunos de 6 a 14 anos) e o ensino médio (para alunos de 15 a 17 anos).

A primeira meta do Plano Nacional de Educação (PNE) é "universalizar, até 2016, a Educação Infantil na pré-escola para as crianças de 4 a 5 anos de 
idade e ampliar a oferta em creches de forma a atender, no mínimo, 50\% das crianças de até 3 anos durante a vigência PNE, ou seja, até o ano de 2024."

Segundo os dados do Observatório do PNE (2017), cerca de 90,5\% das crianças de 4 e 5 anos estão sendo atendidas na pré-escola. Isso, no entanto, significa que cerca de 500 mil crianças (9,5\%) ainda não tiveram acesso à educação infantil escolar. Já na etapa de 0 a 3 anos, calcula-se que cerca de 2,4 milhões de crianças estão sem atendimento por não conseguirem vagas nas creches.

A segunda meta do PNE propõe "universalizar o ensino fundamental de 9 anos para toda a população de 6 a 14 anos e garantir que pelo menos 95\% dos alunos concluam essa etapa na idade recomendada, até o último ano de vigência deste PNE." (OBSERVATÓRIO DO PNE, 2017). Segundo o Observatório do PNE, 97,7\% das crianças/adolescentes nessa idade, em 2015, cursavam o ensino fundamental, ou seja, cerca de 430 mil crianças permanecem fora da escola. E a porcentagem de jovens de 16 anos que, em 2015, concluíram o ensino fundamental era de 76\%.

A terceira meta do PNE tem como objetivo "universalizar, até 2016, o atendimento escolar para toda a população de 15 a 17 anos e elevar, até o final do período de sua vigência, a taxa líquida de matrículas no ensino médio para 85\%." (OBSERVATÓRIO DO PNE, 2017). Segundo o Observatório do PNE, em 2015, apenas 84,3\% dos jovens de 15 a 17 anos frequentavam a escola, ou seja, aproximadamente 1,5 milhão de jovens dessa idade estavam fora das salas de aulas. Em relação aos jovens de 15 a 17 anos, que deveriam estar cursando o ensino médio (taxa líquida), apenas 62,7\% o faziam, em 2015.

As taxas do último Censo da Educação Básica no Brasil, 2015, mostram que cerca de 2,5 milhões de crianças, adolescentes e jovens de 4 a 17 anos estão fora da escola. Predominam entre eles os filhos de famílias mais pobres, com renda per capita de até 1/4 do salário mínimo, negros, indígenas e pessoas com deficiência. ${ }^{3}$

\footnotetext{
${ }_{3}$ As informações sobre as metas do PNE e sobre as porcentagens das crianças, dos adolescentes e jovens matriculados nas escolas de educação básica ou excluídos delas, foram extraídos do Observatório do PNE (2017).
} 
A escola da educação básica é uma das instituições sociais de nossa sociedade, que carrega e reproduz a violência institucionalizada dessa mesma sociedade. $\bigcirc$ fato de um número espantoso de crianças e jovens, das famílias mais empobrecidas e marginalizadas, estarem excluídos desse ambiente formativo é apenas uma das manifestações mais gritantes de violência que atinge nossa realidade nacional. Pode-se enumerar outras expressivas formas de violência vinculadas à educação escolar, como a qualidade da formação escolar dos filhos das classes populares em contraposição à qualidade da formação escolar dos filhos das classes dominantes; o preconceito generalizado contra o aluno negro, homossexual, nordestino, deficiente; e os atos agressivos de alunos contra os professores.

jornal da SBPC, nos primeiros dias de junho de 2017, traz as seguintes reportagens: "Professores dizem sofrer censura de pais e alunos nas salas de aula"; "Adeptos de religiões afro-brasileiras relatam preconceito em sala de aula"; "Violência relacionada à identidade de gênero e orientação sexual faz alunos abandonarem escola"; "A comunidade LGBT está sendo expulsa das escolas', diz ativista pelos direitos humanos".

Por outro lado, enquanto ambiente que se propõe a ser formativo, a escola pode desenvolver perspectivas e formas de atuação e de reflexão que se contraponham à virulência que pesa sobre ela e seus participantes. E nessa direção, o diálogo com o texto de Walter Benjamin Para a Crítica da Violência, bem como as reflexões educacionais de Adorno e a narrativa estética de Rosa sobre as manifestações de violência vigentes na sociedade e na escola podem nos ajudar a refletir sobre esse contexto de agressão que invade a prática educativa, e nos fornecer subsídios para a formulação de propostas contra a situação de barbárie que nos domina e nos desafia.

\section{WALTER BENJAMIN E A CRÍTICA DA UIOLÊNCIA}

Neste ensaio de 1921, Benjamin elabora uma crítica da violência do direito, que é o tipo de violência que o Estado, através do aparato legal, exerce 
por instaurar e manter o seu poder sobre quem a ele está sujeito. De acordo com o autor, "A instauração do direito é instauração do poder e, enquanto tal, um ato de manifestação imediata de violência." (BENJAMIN, 2011, p. 148). Ao mesmo tempo, constata que é possível a resolução não violenta de conflitos e que as pessoas particulares utilizam o diálogo como uma técnica de civilidade no entendimento. "O que quer dizer que existe uma esfera da não violência no entendimento humano que é totalmente inacessível à violência: a esfera própria da 'compreensão mútua', a linguagem." (BENJAMIN, 201 l, p. 139). Por outro lado, Benjamin (2011, p. 136) pergunta "por que a violência teve que assumir a forma legal para regulamentar as tensões dos homens na sociedade?" Ao levantar essa questão, Butler (2017, p. 77) abre outra trajetória em seu pensamento:

Existe outra forma de violência que não seja coercitiva, aliás, uma violência que possa ser invocada e empreendida contra a força coercitiva do direito? [...] haveria uma violência que não seja apenas empreendida contra a coerção, mas que seja em si não coercitiva e, nesse sentido (ou ainda em outros), fundamentalmente não violenta? Ele se refere a essa violência não coercitiva como "não sangrenta", e isso parece implicar que ela não é empreendida contra corpos humanos e vidas humanas.

Benjamin (2011) propõe a existência de um tipo de violência que é "puro meio", que não se enquadra nas categorias usuais de coerção, e a nomeia violência divina. E, na tentativa de explicitar esse novo tipo de violência, a contrapõe à violência mítica, que traz como protótipo o mito de Níobe, que como uma simples mortal, julgou-se superior e mais fértil que Leto, a Deusa da Fertilidade. Níobe foi castigada por Ártemis e Apolo, pela petulância de seu ato de fala e por ter provocado o destino. "A violência desaba [...] sobre Níobe a partir da esfera incerta e ambígua do destino." (BENJAMIN, 201 1, p. 147).

Se a violência mítica é instauradora do direito, a violência divina é aniquiladora do direito; se a primeira é ameaçadora, a segunda golpeia; se a primeira é sangrenta, a divina é letal de maneira não-sangrenta [...] A violência mítica é sangrenta, exercida em favor próprio, contra a mera 
vida; a violência divina e pura se exerce contra toda a vida, em favor do vivente. (BENJAMIN, 201 l, p. 150, 152).

ensaio de Benjamin apresenta ainda outras nuances para se entender o conceito de violência divina. Com apoio de Sorel, distingue entre a greve geral política, que está a serviço da proteção do Estado, e a greve geral proletária, cuja finalidade primeira é aniquilar o poder do Estado. A primeira se caracteriza como violenta; a segunda, como não violenta, como puro meio. A primeira como instauradora do direito; a segunda como anarquista (BENJAMIN, 2011 , p. 141-143). Ou seja, o conceito de violência divina se aproxima da violência revolucionária. "Mas, se a existência da violência para além do direito, como pura violência imediata, está assegurada, com isso se prova que, e de que maneira, a violência revolucionária - nome que deve ser dado à mais alta manifestação da violência pura pelo homem - é possível." (BENJAMIN, 2011 , p. 155).

Na perspectiva de Butler, Benjamin, nesse ensaio, trabalhou em duas frentes ao mesmo tempo: a política e a teológica. De um lado, apresenta "as condições para uma greve geral que resultasse na paralização e dissolução de todo um sistema legal, e, de outro, a noção de um deus divino cujo mandamento oferece um tipo de injunção irredutível ao direito coercitivo." (BUTLER, 2017, p. 79). A autora acrescenta outro elemento importante para se entender a forma como a violência divina é comunicada. Ela toma a forma de um mandamento - não matarás - que não é nem despótico nem coercitivo, pois "o mandamento transmite um imperativo justamente sem ter a capacidade para, de algum modo, impor o imperativo que comunica." (BUTLER, 2017, p. 80). Se o mandamento não é resultado de um direito coercitivo, ele não induz à culpa. Ele é um imperativo que não impõe, deixa aberto tanto o modo de sua aplicabilidade, quanto as possibilidades de interpretação, inclusive as condições em que pode ser recusado. E, continua a autora: "[...] sugiro que o mandamento, como concebido por Benjamin, é não só a base para a crítica da violência legal, mas também a condição para uma teoria da responsabilização que tem em seu núcleo um esforço contínuo pela não violência (BUTLER, 2017. p. 81). A violência, pois, fora do direito positivo e da modalidade mítica, é 
caracterizada, ao mesmo tempo, como revolucionária e divina, pois ela é pura, imediata, genuína (BUTLER, 2017, p. 91).

A nuance da violência divina que mais nos interessa destacar no ensaio de Benjamin diz respeito à nossa área de atuação:

Esta violência divina não é atestada apenas pela tradição religiosa, mas encontra-se também na vida presente em pelo menos uma manifestação consagrada. $\bigcirc$ poder que se exerce na educação, que em sua forma plena está fora da alçada do direito, é uma de suas formas manifestas. Estas não se definem pelo fato de que Deus em pessoa exerça essa violência de modo imediato, por milagres, mas por aqueles momentos de cumprimento não-sangrento, golpeador, expiador de culpa. E, enfim, pela ausência de qualquer instauração de direito. (BENJAMIN, 201 l, p. 152).

poder que se exerce na educação é uma das formas manifestas da violência divina. Anteriormente, nesse mesmo ensaio, o autor já tinha destacado que "o comportamento assumido no exercício de um direito deve, sob determinadas circunstâncias, ser caracterizado como violência." (BENJAMIN, 201 1, p. 129). Na citação última, ele vai além: o comportamento do docente no exercício de sua responsabilidade de educar, de formar, pode ser caracterizado como uma violência divina? Parece-me que sim, sobretudo se o docente visa formar o cidadão crítico, o trabalhador solidário, para uma sociedade sem exploração, justa e verdadeiramente humana. A força messiânica da violência divina que insufla a greve geral proletária contra a violência do direito é a mesma que impulsiona o poder de atuação do docente na responsabilidade social de formar os futuros profissionais da sociedade. Tomada em seu sentido pleno, para Benjamin, a práxis educativa docente carrega em seu realizar-se uma carga revolucionária intensa. Assim como Deus tem a ver com a greve geral proletária, que busca a destruição do estado de direito e a construção de uma nova sociedade; assim também Deus tem a ver com a atitude e o poder do educador em sua práxis formativa. A violência divina contempla intensamente o processo pedagógico. "O homem interior, ligado à preocupação ética, é o lugar da intensidade messiânica." (BUTLER, 2017, p. 92). 


\section{A UIOLÊNCIA NOS ESCRITOS DE THEODOR ADORNO}

Vou apresentar apenas dois momentos da Dialética Negativa (2009) em que Adorno aborda a questão da violência. Ele já havia denunciado, em outros escritos, como a filosofia, em sua longa trajetória histórica, tinha esquecido e/ou não se preocupado com a dor e com a violência do homem no mundo. No aforismo "O Sofrimento é Físico", ele ressalta a cobrança que o corpo faz à razão, na perspectiva de superar o sofrimento, e apresenta o teórico crítico como aquele que se empenha radicalmente na transformação da sociedade, que gera a opressão, a dominação, a dor: "O momento corporal anuncia ao conhecimento que o sofrimento não deve ser, que ele deve mudar. 'A dor diz: pereça'. Por isso, o especificamente materialista converge com aquilo que é crítico, com a práxis social transformadora." (ADORNO, 2009, p. 173).

momento histórico de Adorno vivia as lutas e as ameaças de ideologias opostas, em pleno estado da Guerra Fria, na criação de arsenais atômicos e de tecnologias bélicas avançadas. E o filósofo afirmava que a possibilidade de organização do mundo com menos violência "teria o seu telos na negação do sofrimento físico do último de seus membros e nas formas de reflexão intrínsecas a esse sofrimento." Tal organização, insistia, "é o interesse de todos e não é paulatinamente realizável senão por uma solidariedade transparente para ela mesma e para todo vivente." (ADORNO, 2009, p. 174). ${ }^{4}$

Das "Meditações sobre a Metafísica", parte final da Dialética Negativa, extraio dois tópicos. $\bigcirc$ primeiro, intitulado "Depois de Auschwitz", em que o autor retrata o conceito de espectador, enfatizando que os homens, sem exceção, encontram-se em estado de encanto, pois ninguém é capaz de amar e, ao mesmo tempo, cada um se sente, por isso, muito pouco amado. A atitude do espectador reflete aquele que olha, observa, acompanha, mas não se envolve, não toma posição diante da violência e do sofrimento do outro. Enquanto espectador, ele oscila entre a ataraxia involuntária e o embrutecimento. Ataraxia indica a completa ausência de inquietações, de perturbações mentais. A ataraxia involuntária é diferente da ataraxia estoica, pois esta era o resultado

${ }_{4}$ Cf. Pucci (2017). 
de uma ascese espiritual, de um domínio das paixões. A ataraxia involuntária é, às avessas, fruto de um ser dominado pelo sentimento de impotência, de medo, de covardia; uma indiferença consentida. E, diz o frankfurtiano: "As duas coisas - a ataraxia involuntária e o embrutecimento - são vida falsa." (ADORNO, 2009, p. 301$)^{5}$

No tópico "Metafísica e Cultura", Adorno questiona a teoria da identidade de Hegel, quando esta, nomeada como "ciência da experiência da consciência", na realidade desvia a consciência da experiência histórica, em que predomina a dor, a violência. "No vivente, a camada somática e distante do sentido é palco do sofrimento que queimou sem qualquer consolo nos campos de concentração tudo o que o espírito possui de tranquilo, e, com ele, a sua objetivação, a cultura." (ADORNO, 2009, p. 303). E diante do que aconteceu com os judeus, mas também com ciganos, com homossexuais, com resistentes e oponentes ao nazismo, com comunistas e socialistas, com testemunhos de Jeová, com intelectuais poloneses e outros, todos eles vítimas do nazismo, brada o frankfurtiano com radical negatividade: "Auschwitz demonstrou de modo irrefutável o fracasso da cultura. [...] Toda cultura depois de Auschwitz, inclusive sua crítica urgente, é lixo." (ADORNO, 2009, p. 304).

A violência aparece também, e de forma intensa, em seus escritos estéticos. Vou apresentar algumas poucas citações, que se evidenciam por si mesmas:

[...] mas valia mais desejar que um dia [...] a arte desapareça do que ela esquecer o sofrimento, que é a sua expressão e na qual a forma tem a sua substância. (ADORNO, 2011, p. 391).

Mas que seria a arte enquanto historiografia, se ela se desembaraçasse da memória do sofrimento acumulado? (ADORNO, 201 l, p. 392).

El sufrimiento, el dolor, la disonancia, pertenecen a lo bello como algo esencial y no como un mero accidente. (ADORNO, 2013, p. 267).

Que el arte moderno se convierte por sí mismo en lo que verdaderamente fue el arte en un sentido central: en el intérprete del sufrimiento que en verdad ha sido reprimido. (ADORNO, 2013, p. 498).

5 Cf. texto de Pucci (2014). 
São os escritos educacionais do frankfurtiano os que mais se aproximam da proposta da educação como uma manifestação da violência divina. O Ensaio "Educação após Auschwitz", de 1965, apresenta um imperativo que, para Adorno (1995b, p. 1 19), deve ser a orientação primeira do processo educacional: "A exigência que Auschwitz não se repita é a primeira de todas para a educação." E justifica com radicalidade o imperativo: "Fala-se da ameaça de uma regressão à barbárie. Mas não se trata de uma ameaça, pois Auschwitz foi a regressão; a barbárie continuará existindo enquanto persistirem, no que tem de fundamental, as condições que geram esta regressão. É isto que apavora." (ADORNO, 1995b, p. 1 19).

No ensaio "Tabus a respeito do magistério", também de 1965, Adorno retoma, com pesar e tenacidade, a tragédia insana vivida por ele e seus contemporâneos poucos anos atrás: "A minha geração vivenciou o retrocesso da humanidade à barbárie, em seu sentido literal, indescritível e verdadeiro." E mostra como essa realidade, terrivelmente desumana, atinge a escola e limita as suas ações em prol da resistência. "Esta é uma situação em que se revela o fracasso de todas aquelas configurações para as quais vale a escola. Enquanto a sociedade gerar a barbárie a partir de si mesma, a escola tem apenas condições mínimas de resistir a isso." (ADORNO, 1995c, p. 116). E por barbárie claramente se referia ao extermínio, ao preconceito delirante, à opressão, ao genocídio, à tortura. E não obstante a barbárie existente na sociedade adentrar os átrios escolares e se contrapor frontalmente à formação cultural, Adorno (1995c, p. 1 17) ainda acreditava no potencial da formação educativa: "[...] é preciso contrapor-se à barbárie principalmente na escola. [...] A desbarbarização da humanidade é o pressuposto imediato da sobrevivência. Este deve ser o objetivo da escola, por mais restritos que sejam seu alcance e suas possibilidades."

No ensaio "Educação contra a Barbárie", de 1968, um ano antes de sua morte, no diálogo com Becker, na Rádio de Hessen, ele insiste na tese de que "desbarbarizar tornou-se a questão mais urgente da educação." E recoloca o problema de "saber se por meio da educação é possível transformar algo de decisivo em relação à barbárie." (ADORNO, 1995a, p. 155). E, nesse contexto, 
apresenta uma conceituação mais detalhada e abrangente sobre seu objeto de análise:

\begin{abstract}
Entendo por barbárie algo muito simples, ou seja, que, estando na civilização do mais alto desenvolvimento tecnológico, as pessoas se encontrem atrasadas de um modo peculiarmente disforme em relação a sua própria civilização - e não apenas por não terem em sua arrasadora maioria experimentado a formação nos termos correspondentes ao conceito de civilização, mas também por se encontrarem tomadas por uma agressividade primitiva, um ódio primitivo ou, na terminologia culta, um impulso de destruição, que contribui para aumentar ainda mais o perigo de que toda esta civilização venha a explodir, aliás uma tendência imanente que a caracteriza. (ADORNO, 1995a, p. 155).
\end{abstract}

Becker, seu interlocutor, ainda não satisfeito com a conceituação de barbárie elaborada por Adorno, coloca-lhe uma questão muito precisa: a afirmação de um político de que os distúrbios de rua em Bremen, motivados pelos aumentos tarifários dos transportes, eram uma comprovação da falência da formação política, pois a juventude se manifestou por meio de formas bárbaras contra uma posição pública, acerca de cuja justeza poderia haver várias visões. Qual o juízo de Adorno sobre essa questão? Na resposta, o pensador frankfurtiano se aproxima de seu amigo Benjamin em duas dimensões essenciais. Primeiramente, na análise da atitude dos estudantes, afirmando que a educação se manifestou nos atos públicos como um meio, não como um direito positivo: "Se existe algo que as manifestações dos secundaristas de Bremen demonstram é precisamente a conclusão de que a educação política não foi tão inútil como sempre se afirma; não se converteram em obedientes instrumentos da ordem vigente." A seguir, dirige uma crítica radical ao direito positivo, como instrumento de violência do Estado:

A forma de que a ameaçadora barbárie se reveste atualmente é a de, em nome da autoridade, em nome de poderes estabelecidos, praticarem-se precisamente atos que anunciam, conforme sua própria configuração, a deformidade, o impulso destrutivo e a essência mutilada da maioria das pessoas. (ADORNO, 1995a, p. 159). 
E, ainda, impulsionado pelos questionamentos colocados por Becker, Adorno se aproxima cada vez mais do conceito de Benjamin da violência como meio, da violência divina, da violência revolucionária. Apresento citaçõeschave suas:

[...] em circunstâncias em que a violência conduz inclusive a situações bem constrangedoras em contextos transparentes para a geração de condições humanas mais dignas, a violência não pode sem mais nem menos ser condenada como barbárie. (ADORNO, 1995a, p. 159-160).

Se examinarmos mais de perto os acontecimentos que ocorrem atualmente na rebelião estudantil, então descobriremos que de modo algum se trata neste caso de erupções primitivas de violência, mas em geral de modos de agir politicamente refletidos. (ADORNO, 1995a, p. 160).

Os acontecimentos são entendidos, na pior das hipóteses, como estando à serviço da humanidade; [...] podemos apreender de um modo radical, a partir desses exemplos tão atuais, a diferença entre o que é e o que não é barbárie. (ADORNO, 1995a, p. 160).

E Adorno conclui sua tese enfatizando a dimensão formativa da educação política, que, tal como a violência divina, manifesta-se expressivamente na práxis educacional das salas de aula:

Esta questão central para mim é decisiva; é a isto que me refiro com a função do esclarecimento, e de maneira nenhuma à conversão de todos os homens em seres inofensivos e passivos. Ao contrário: essa passividade inofensiva constitui ela própria, provavelmente, apenas uma forma de barbárie, na medida em que está pronta para contemplar o horror e se omitir no momento decisivo. (ADORNO, 1995a, p. 164)

\section{A UIOLÊNCIA COMO PURO MEIO EM A BENFAZEJA, DE GUIMARÃES ROSA}

Na leitura e análise interpretativa do conto de Guimarães Rosa, A Benfazeja, em diálogo com as reflexões estético-filosóficas de Theodor 
Adorno, percebemos que a questão da violência como meio se manifesta de forma expressiva em pelo menos duas atitudes de personagens da narrativa. Apresento um resumo do referido conto de Rosa para nele constatar essas manifestações da violência.

\begin{abstract}
"A Benfazeja" é um dos 21 contos de Primeiras Estórias, de Guimarães Rosa, publicado em 1962. A estória se desenvolve em forma de diálogo entre o narrador e os moradores do lugarejo a respeito de uma mulher, Mula-Marmela, que, de acordo com os relatos, teria assassinado seu marido Mumbungo, sujeito perverso, e teria sido responsável pela cegueira e, depois pela morte, de seu enteado, Retrupé, de quem era guia em seu perambular pelo lugarejo e que reproduzia as atrocidades do pai. O narrador, que veio de fora, um observador atento e crítico, analisa a trajetória da envelhecida e alquebrada mulher, que, mesmo amando e sendo amada pelo seu marido, e cuidando como se fosse mãe, e sendo respeitada pelo seu enteado, assassinara a ambos para livrar a comunidade dos malefícios dos dois facínoras. Ele, em contraposição aos moradores, se propõe a destacar a face benfeitora de Mula-Marmela, sua sina histórica, e questionar o desprezo, o não reconhecimento do vilarejo por ela. O conto termina com mais uma ação benfazeja de Mula-Marmela - ao se retirar para sempre do lugar onde vivia, agora sozinha, leva consigo um cão em decomposição para livrar os moradores dos perigos da pestilência - e com a esperança do narrador de que os filhos dos moradores, ao conhecerem a verdadeira história da mulher, resgatem a sua imagem singela e altruísta. (PUCCI; AQUINO; ROMEIRO, 2015, p. 163).
\end{abstract}

Como se pode perceber pelo resumo do conto, a violência se manifesta de forma intensiva e dominante em todos os momentos da narrativa: nas duas mortes perpetradas por Mula-Marmela de pessoas que lhe eram próximas e queridas; no preconceito exacerbado da comunidade para com a velha senhora, que sempre queria fazer o bem; pela postura incisiva e contínua do narrador que, a todo o momento, questiona os olhares enviesados e maldosos dos moradores; e pelo triste fim de Mula-Marmela, que se retira da comunidade para terminar seus dias na solidão. Mas nem toda violência, caracterizada no conto, tem a mesma dimensão. Há, como salientado anteriormente, duas 
atitudes dos personagens em que a violência se caracteriza como uma violência do bem.

A primeira é a de Mula-Marmela, apelido injurioso que a comunidade atribuiu àquela "abominada" mulher, "velha e feia, feita tonta", "guia de um cego", "que tinha dores nas cadeiras: andava meio se agachando; com os joelhos para diante", mas que "olhava para tudo com singeleza e admiração." (ROSA, 2005, p. 161, 165). Mula-Marmela cometeu dois crimes: assassinou seu marido, que "era hediondo, o cão de homem, calamidade horribilíssima, perigo e castigo para os habitantes do lugar. [...] célebre-cruel e iníquo, muito criminoso, homem de gostar do sabor de sangue, monstro de perversias", e cegou e matou seu enteado, "homem maligno, com cara de matador de gente [...] sanguinaz e cruel-perverso quanto o pai." (ROSA, 2005, p. 162, 166). Nesses atos ela afrontou o mandamento divino e também as leis do direito positivo. $\bigcirc$ narrador, porém, como seu advogado de defesa, apresenta dois argumentos substanciosos a seu favor: primeiro, ela assassinou seu próprio marido, a quem muito amava, e seu enteado, que, em momentos de ternura e de desatino, a chamou "mamãe", e nesses atos radicais ela se sacrificou a si mesma para livrar a comunidade das ações dos dois facínoras, além de que, ao final do conto, toma em seus braços o cão que se decompunha, carrega-o para fora da comunidade para livrá-la de possíveis contaminações.

segundo argumento em defesa da mulher sertaneja se refere ao destino do herói trágico grego, que transgride as leis dos homens na sina de salvar a comunidade, sacrificando-se a si mesmo. Mula-Marmela carregava em seu franzino corpo uma terrível incumbência: a violência de ir contra ela mesma para cumprir uma determinação. Assim se posiciona o narrador:

Se eu disser o que sei e pensam, vocês inquietos se desgostarão. Nem consintam, talvez, que eu explique, acabe. A mulher tinha de matar, tinha de cumprir por suas mãos o necessário bem de todos, só ela mesma poderia ser a executora - da obra altíssima, que todos nem ousavam conceber, mas que, em seus escondidos corações, imploravam. Só ela mesma, a Marmela, que viera ao mundo com a sina presa de amar aquele homem, e de ser amada dele; e, juntos, enviados. Por quê? Em volta de nós, o que há é a sombra mais fechada - coisas gerais. [...] Só ela poderia 
matar o homem que era o seu, ela teria de matá-lo. Se não cumprisse assim [...] ela enlouqueceria? (ROSA, 2005, p. 164).

Reforço a argumentação do narrador com o comentário de Cézar (2003, p. 78), no texto $A$ presença do trágico em A Benfazeja, de João Guimarães Rosa: "Trata-se da não-escolha da escolha, trata-se da necessidade que sobrecarrega e sobredetermina o ato."

Não estaria Mula-Marmela, não obstante ter infringido a lei dos homens e até o mandamento divino, carregando dentro de si um potencial de violência do bem que ultrapassaria as medidas do direito positivo, bem como não colidiria com o imperativo divino, que não é despótico e nem coercitivo e permite interpretações? "Repararam - diz o narrador - como olha para as casas com olhos simples, livres do amaldiçoamento de pedidor? E não põe, no olhar as crianças, o soturno de cativeiro que destinaria aos adultos. Ela olha para tudo com singeleza e admiração." (ROSA, 2005, p. 165). Mula-Marmela, a benfazeja!

A segunda manifestação do conto em que a maneira de agir - a práxis política - se caracteriza como violência do bem ou violência como meio será observada no narrador do conto. Ele não nasceu no vilarejo, veio de fora, e, durante todo o conto, questiona o ódio e os preconceitos da comunidade e cria tentativas éticas de formar as consciências das pessoas. À semelhança de Sócrates, dialoga reflexiva e criticamente com os moradores, ora apontando a ambivalência do comportamento deles, ora admoestando-os de suas ações - "Dizem-na maldita: será; é? [...] "E vocês ainda podem culpar esta mulher, a Marmela, julgá-la, achá-la vituperável?" (ROSA, 2005, p. 165, 167); ora acusando-os de a terem expulsado do lugarejo (PUCCI; AQUINO; ROMEIRO, 2015, p. 166).

Santos (2006, p. 3), em seu texto $O$ narrador persuasivo: um olhar benfazejo, capta com perspicácia as características desse personagem central do conto: 
Narrador onisciente, seu olhar é profundo e consegue captar o que ninguém viu. Sua sabedoria vem justamente deste olhar, que não conhece apenas o presente da personagem, mas todo o processo pelo qual ela passou. Somente ele consegue ter um olhar perscrutador, benevolente e cúmplice, porque conhece as sutilezas da alma humana.

Com seu "olhar perscrutador, benevolente e cúmplice", o narrador de A Benfazeja desenvolve junto à comunidade e também junto aos leitores intérpretes do conto uma atividade profundamente formativa, transforma-se em um educador crítico; mesmo não fazendo parte da instituição escola, tenta abrir os olhos e, sobretudo, os corações dos moradores, por meio do diálogo, do debate, da persuasão; manifesta em suas atitudes educacionais a violência enquanto meio, a violência divina no ato de ensinar. É um educador que não desiste nunca, ele elabora um tipo de práxis formativa mediante sua intervenção teórica e questionadora; e, mesmo não obtendo resultados imediatos, mesmo não tendo conseguido convencer os moradores de seus desatinos, alimenta um olhar de esperança em relação ao amanhã. E, no último parágrafo do conto, faz um expressivo apelo aos moradores do lugarejo, uma quase intimação:

E nunca se esqueçam, tomem na lembrança, narrem a seus filhos, havidos ou vindouros, o que vocês viram com esses olhos terrivorosos, e não souberam impedir, nem compreender, nem agraciar. De como, quando ia a partir, ela avistou aquele um cachorro morto, abandonado e meio já podre, na ponta-da-rua, e pegou-o às costas, o foi levando: - se para livrar o logradouro e lugar de sua pestilência perigosa, se para piedade de dar-lhe cova em terra, se para com ele ter com quem ou quê se abraçar, na hora de sua grande morte solitária? Pensem, meditem nela, entanto. (ROSA, 2005, p. 170).

\section{A UIOLÊNCIA DIUINA NA FORMAÇÃO DOS EDUCANDOS}

Termino esta intervenção retomando alguns eixos estético-filosóficos sobre violência e educação a partir dos pensadores que nos ajudaram a refletir sobre essa realidade social e política. 
Walter Benjamin nos chama a atenção para o tour de force do trabalho do educador, que conduz os educandos, pelo poder de sua palavra e de sua experiência, a irem além da mera sobrevivência, a se transformarem em seres pensantes e ativos no confronto com um contexto social marcado por tragédias e catástrofes, com ressonâncias intensas no interior da escola. Tratase da violência divina ou revolucionária que brota de profundis dos docentes e atinge com intensidade os educandos em sua luta para minorar os sofrimentos.

Theodor Adorno, ao mesmo tempo em que nos adverte sobre a vigência e a atualidade da barbárie, apresenta indicações educativas e estéticas de como enfrentá-la: " $\bigcirc$ único poder efetivo contra o princípio de Auschwitz seria a autonomia, para usar a expressão kantiana; o poder para a reflexão, a autodeterminação, a não participação." (ADORNO, 1995b, p. 125). E, no ensaio "A Arte é alegre?", insistirá: "A afirmativa de que após Auschwitz não é mais possível escrever poesia, não deve ser cegamente interpretada, mas com certeza depois que Auschwitz se fez possível e que permanece possível no futuro previsível, a alegria despreocupada na arte não é mais concebível." (ADORNO, 2001, p. 16).

Guimarães Rosa, por sua vez, por meio do narrador de A Benfazeja, nos apresenta uma forma didática e persuasiva de como lidar com a violência que se manifesta nos alunos sob nossa responsabilidade em salas de aula. Um olhar "perscrutador, benevolente, cúmplice e esperançoso" sobre cada um deles pode nos apontar indícios reveladores e intervenções frutíferas. Desse modo, vê-se que a estética tem muito a contribuir com o campo da conduta ética e da moral, uma vez que, como vimos anteriormente, o exemplo da Benfazeja traz uma situação de afronta à ordem legal porque está vinculado a uma outra lógica, mais preocupada com a formação da comunidade e menos com a sua funcionalidade sistêmica.

○ conceito de violência divina se aproxima nesse sentido do conceito de práxis aristotélico, ou seja, enquanto a violência do sistema tem sempre um fim fora da ação, ele se contenta com a realização das suas finalidades no interior do próprio ato em si. Portanto, é pura potência, na medida em que considera os saberes pedagógicos como um campo autônomo do conhecimento que, como tal, opera movimentos próprios de validação e de refutação de posições que 
pretendem se justificar como conhecimento. Dessa forma, a violência divina é puro meio, porque tem em vista não uma educação que prepare para o mercado de trabalho, o que implicaria submetê-la à heteronomia da ação, mas, pelo contrário, sendo pura potência requer a formação de autonomias plenas, cidadanias ativas e críticas. Nada mais interessante para pensar aqui, em segunda instância, o próprio pensamento que guia as ações, opondo, assim, resistência à violência da racionalidade meios e fins, já instaurada no cotidiano sob o manto da ordem legal instituída.

E diante da situação de violência que o sistema capitalista e o atual quadro político nacional nos impõem, contraponho uma reflexão da jornalista gaúcha Eliane Brum, em recente texto Cotidiano de exceção. Como lutar pela democracia aprendendo sobre a tirania:

Resistir [...] é também deixar de reagir por reflexo - e passar a reagir a partir da reflexão. Quando tudo parece caótico, quando tudo fica meio misturado e parecido, é preciso olhar para os fatos. Olhar para os fatos com toda a atenção. São eles que nos apontam onde estão as verdades e nos ajudam a enxergar onde está a manipulação, assim como a falsificação. $O$ pensamento é ainda a melhor forma de resistência. (BRUM, 2017).

\section{REFERÊNCIAS}

ADORNO, T. W. A Arte é alegre? Tradução Newton Ramos de Oliveira. In: PUCCI, B.; RAMOS-DE-OLIVEIRA, N.; ZUIN, A. A. S. (Org.). Teoria Crítica, Estética e Educação. Piracicaba: Ed. UNIMEP; Campinas: Autores Associados/FAPESP, 2001. p. 11-18.

ADORNO, T. W. A Educação contra a Barbárie. Tradução Wolfgang Leo Maar. In: ADORNO, T. W. (Org.). Educação e Emancipação. Rio de Janeiro: Paz e Terra, 1995a. p. 155-168.

ADORNO, T. W. Dialética negativa. Tradução Marco Antônio Casanova. Rio de Janeiro: Zahar, 2009.

ADORNO, T. W. Educação após Auschwitz. Tradução Wolfgang Leo Maar. In: ADORNO, T. W. (Org.). Educação e Emancipação. Rio de Janeiro: Paz e Terra, 1995b. p. 129-138. 
ADORNO, T. W. Estética (1958/59). Tradução Silvia Schwarzböck. Buenos Aires: Las Cuarenta, 2013.

ADORNO, T. W. Tabus a respeito do Magistério. Tradução Wolfgang Leo Maar. In: ADORNO, T. W. (Org.). Educação e Emancipação. Rio de Janeiro: Paz e Terra, 1995c. p. 97-118.

ADORNO, T. W. Teoria estética. Tradução Artur Morão. Lisboa: Edições 70, 2011.

BENJAMIN, W. Para a crítica da violência. Tradução Ernani Chaves. In: BENJAMIN, W. (Org.). Escritos sobre mito e linguagem. 2. ed. São Paulo: Duas Cidades; Editora 34, 2013. p. 121-156.

BRUM, E. Cotidiano de exceção. Como lutar pela democracia aprendendo sobre a tirania. El País, 29 maio 2017. Disponível em: <http://brasil.elpais. com/brasil/2017/05/29/opinion/1496068623_644264.html>. Acesso em: 10 mar. 2018.

BUTLER, J. Caminhos divergentes: judaicidade e crítica do sionismo. Tradução Rogério Bettoni. São Paulo: Boitempo, 2017.

CÉZAR, A. C. A presença do trágico em A Benfazeja, de João Guimarães Rosa. Contexto: Revista do Programa de Pós-Graduação em Letras, Universidade Federal do Espírito Santo, n. 10, p. 77-82, 2003.

OBSERVATÓRIO DO PNE. Porcentagem de crianças do $3^{\circ}$ ano do Ensino Fundamental com aprendizagem adequada em leitura. Disponível em: $<$ http://www.observatoriodopne.org.br/metas-pne>. Acesso em: 01 jun. 2017.

PUCCI, B.; AQUINO, L. C. A. de; ROMEIRO, A. E. A Obra de Arte como Práxis. Artefilosofia, Ouro Preto, UFOP, n. 19, p. 156-171, 2015.

PUCCI, B. Formação e qualificação profissional: desafios urgentes para a Filosofia da Educação. In: GOMES, L. R. et al. (Org.). Filosofia da Educação: entre a formação de educadores e a qualificação profissional. São Paulo: Cortez, 2017.

PUCCI, B. Theodor Adorno e a frieza burguesa em tempos de tecnologias digitais. In: PUCCI, B.; FRANCO, R.; GOMES, L. R. (Org.). Teoria Crítica na era digital: desafios. 1. ed. São Paulo: Nankin Editorial, 2014. v. 1. p. 47-60. 
ROSA, J. G. A Benfazeja. In: ROSA, J. G. (Org.). Primeiras Estórias. Rio de Janeiro: Nova Fronteira, 2005. p. 161-170.

SANTOS, I. C. dos. O narrador persuasivo: um olhar benfazejo. Revista Garrafa, Faculdade de Letras, UFRJ, v. 1, n. 1 1, 2006. Disponível em: < http:// www.ciencialit.letras.ufrj.br/garrafal l/vl/iolandacristina.html>. Acesso em: 10 mar. 2018.

Recebido em:: 17 de outubro de 2017 Aceito em:: 03 de abril de 2018

Endereço para correspondência: Rodovia do Açúcar, Km 156, Taquaral, 13400-91 1, Caixa postal 68, Piracicaba, São Paulo, Brasil; puccibru@gmail. $\mathrm{com}$ 